\title{
Student Rating of Teaching Behaviour of Chemistry Teachers in Public Secondary Schools in Ekiti State
}

\author{
Oluwatayo, James Ayodele Ph.D. \\ Faculty of Education \\ Ekiti State University, Ado-Ekiti, Nigeria \\ GSM: +234 (0) 8033964547 \\ E-mail: ayotayor@yahoo.com
}

Received: 05-02- 2013

Accepted: 06-04- 2013

Published: 01-07- 2013

doi:10.7575/aiac.ijels.v.1n.1p.1

URL: http://dx.doi.org/10.7575/aiac.ijels.v.1n.1p.1

\begin{abstract}
The study investigated student-rating of teaching behaviour of Chemistry teachers in public secondary schools in Ekiti State. Participants were 750 SS II Chemistry students (Male=375, Female=375) selected from 75 schools across the 16 local government areas of Ekiti State based on purposive and stratified random sampling techniques. Data were collected using a 30-item Teaching Behaviour Questionnaire (TBQ) clustered into seven categories $\left(\mathrm{CAT}_{\mathrm{i}}=1,2,3, \ldots\right)$ ranging from attendance and punctuality in class to evaluation of students' work. Each item was rated on a five-point scale namely: excellent $=5$; very good $=4$; good $=3$; fair $=2$ and poor $=1$, with reliability coefficient $=0.713$ using Cronbach$\alpha$ and analysed using means, standard deviations, item-total correlations and t-test tested at 0.05 level of significance. Results showed that the teaching behaviour of Chemistry teachers was good; the rating was statistically reliable and devoid of gender bias. It was recommended that teachers should justify the rating ascribed to their teaching behaviour by improving on their pedagogical skills to enhance better learning and performance of students in Chemistry.
\end{abstract}

Keywords: Student-rating, Teaching behaviour, Chemistry teachers, Secondary schools

\section{Introduction}

Teaching behaviour, in the context of this paper, is defined in terms of observable activities, actions and reactions commonly exhibited by the Chemistry teachers during teaching and learning process. These activities, actions and reactions are clustered into seven major categories, namely, attendance and punctuality in class, teacher's personality, class management and organisation, competence in teaching Chemistry concepts, disposition to laboratory work, relationship with students and evaluation of students' work. Presumably, the rating ascribed to teaching behaviour of teachers by the students may be excellent, very good, good, fair or poor depending on the amount of satisfaction and beneficial learning experiences acquired by the students.

The literature on teaching evaluation is saturated with studies that support the use of student's ratings as a means of evaluating teaching effectiveness as applicable to teaching behaviour. The supporters of this evaluative device (e.g. Fox, 1983; Marsh, 1987; Theall \& Franklin, 1990; Rice, Steward \& Huber, 2000; Cross, Dooris \& Weinstein, 2004; Doyles, 2004; Berk, 2005; Murray, 2005; Linse \& Xie, 2011) assert that students are the most qualified sources of obtaining valid and reliable information about their teachers' activities and actions that provide meaningful, productive and learning experiences in the classroom since they invariably interact with the teachers. Specifically, Marsh (1987) notes that student's rating is the only indicator of teaching effectiveness whose validity has been rigorously and thoroughly established. Moreover, Rice et al (2000) and Berk (2005) report that student's rating is a valuable tool for assessing and improving classroom teaching as well as making decisions about the future academic.

\section{Literature Review}

In reality, it is not difficult for students to discern those teachers that attend lessons regularly and punctually from those ones that are truants and habitual late-comers. Research shows that attendance and punctuality are contagious and can impinge on students a kind of positive or negative behaviour. Moore (2003) notes that regular attendance of teachers at lessons is a mark of responsibility, commitment and seriousness with which they take their work while Finlagson (2009) notes that absenteeism is an indication of incompatibility to goals, motivation or expectation of the culture of education. Moreover, Maria-30 (2009) notes that punctuality is a necessity for a teacher to succeed in preparing the students for the day's work. Indeed, attendance and punctuality are crucial in school, in work and in general life and show that a teacher is responsible because an irresponsible teacher cannot be taken seriously. Conjecturally, a teacher who attends classes regularly and punctually is likely to receive higher rating on the positive axis than the one who plays truancy and habitual latecomer to class.

It has long been acknowledged (Erdle, Murray \& Rushtom, 1986) that teacher's personality is a potent factor that can influence student's rating of his or her teaching behaviour. By implication, a teacher who cultivates the habit of dressing appropriately to the class, showing confidence in his or her ability, being enthusiastic at lessons, maintaining emotional 
stability at all situations, exhibiting admirable mannerism in communicating with the students and demonstrating willingness to learn along with the students, is likely to be respected by the students and receive high rating on a personality scale. Conversely, a teacher whose appearance is repulsive, emotionally unstable and uncoordinated during lessons is likely to receive unfavourable rating on a personality scale.

Research shows that teacher's action in the classroom has twice the impact on students' achievement as do school policies regarding curriculum assessment (Marzano, 2003a). Inferentially, students are likely to enjoy teaching in a classroom arranged and organised in such a way conducive to effective management and devoid of chaotic, noisy and poorly managed classroom. Unarguably, a teacher who lacks assertive behaviour over his or her students during lessons is likely to lose respect and receive unfavourable rating on classroom management and organisation scale whereas a teacher who demonstrates appropriate level of dominance, exhibits assertive behaviour and monitors every activity in the Chemistry class is likely to receive high rating on classroom management and organisation scale.

Teaching is generally regarded as a form of interaction or an exchange of knowledge, skills and understanding between a teacher and at least a learner. Research shows that students tend to benefit essentially from the teaching handled by teachers who are competent in terms of subject knowledge, problem-solving ability, creativity, ability to use questioning strategies to arouse interest, effective use of chalkboard to explain Chemistry concepts, efficiency in completing the specified learning content and effective communications to order experience in such a way that new patterns of thinking and new ways of understanding and representing reality are developed in the students (Ugbe \& Agim, 2009; Maja, 2012; Tope, 2012). Indeed, Tope (2012) notes that competent teachers are critical piece in improving students' achievement and closing the achievement gap in Chemistry. Meanwhile, Goubatz (2000) finds that there exist consistently high correlations between student's rating of the amount learned in a course and their overall rating of the teacher. In other words, the more competent a teacher is in teaching Chemistry concepts, the more he or she is likely to be rated by the students.

The most important feature of effective science education is supporting theoretical explanation with actual practices in the laboratory (Morgil, Seyhan \& Secken, 2009). The laboratory practices generally aim to improve the students' abilities by providing observation and equipment utilisation for conducting the experiments. Many researchers in science education (e.g. Bagco \& Simsek, 1999; Adesoji \& Olatunbosun, 2008) admit that laboratory studies increase students' interest and abilities for science subjects. Unfortunately, teachers' disposition to Chemistry laboratory work in Nigerian secondary schools seems to be low. Earlier research in this area (Okebukola, 1987) shows that teachers' attitude to Chemistry laboratory work contributes $10 \%$ to students' performance in Chemistry. This result hardly improves since then as yearly results of students in the Senior School Certificate Examination (SSCE) conducted by the West African Examinations Council (WAEC) and National Examinations Council (NECO) show deplorable standard of performance (Olupohunda, 2012). Deductively, teachers hardly engage students in laboratory work, perhaps until the external examination is approaching. Nevertheless, teachers that frequently conduct Chemistry practicals and actively involve students in practical activities are likely to be rated higher positively than those that shun practical works.

One of the pleasures of teaching is understanding and mutually respectful relationships between teachers and the learners. Pollard (2006) notes that good classroom relationship between teachers and students underpins classroom order and help to create an effective learning environment. Students tend to learn and achieve better in an environment where the teachers take interest in their works, readily available to assist them when having learning difficulties and motivate them to work hard. Indeed, Cooper \& Hyland (2000) state that students tend to like teachers who are firm, flexible, fair and friendly but dislike teachers who have favourites among students or who are unpredictable in their moods. It is likely that teachers who have ethical relationships with their students may be rated high while those with unpleasant relationships may be rated low.

Evaluation is the heart of teaching and learning as it enables the learners gauge their status in line with the learning objectives in terms of cognitive, affective and psychomotor domains (Oluwatayo \& Adebule, 2009). Research shows that many secondary school teachers in Nigeria hardly construct and administer quality evaluation instruments (e.g. tests, examination, interviews, rating scales, etc) because they lack the expertise to do so (Kolawole, 2010). Moreover, some teachers give tests and assignments without providing any feedback to assist the students adjust on their performance. The resultant effect is that students are ill-prepared for both internal and external examinations thus leading to continuous failure (Olupohunda, 2012). However, teachers that give quality tests, examinations and assignments regularly and promptly provide feedback are likely to be rated high while those who place little or no emphasis on evaluation of students' work may be rated low.

Meanwhile, the critics of using students' ratings as a means of evaluating teaching behaviour argue that such evaluative device may be influenced by certain factors including students' rewarding easy-grading teachers with high evaluation scores and harsh-grading teachers with low scores (Trout, 2000), students using the evaluation as a chance to 'let off steam' (Marlin, 1987), inappropriate method of administration of instrument (Seldin, 1993), students' prior interest in the subject whether easy or difficult (Prave \& Baril, 1993), students having limited knowledge of the attributes to be rated (Doyles, 2004), gender bias in rating, that is, male students rating female teachers lower and female students rating male teachers lower (Riger, 1993; Basow, 1994), inconsistency in rating due to halo-effect, generosity error, error of severity and error of central tendency (Ary, Jacobs \& Razavieh, 2002). The foregoing, notwithstanding, it is worth investigating how the students would rate the teaching behaviour of their Chemistry teachers in view of the present notion that some of the secondary school teachers are incompetent in their teaching subjects, culminating to a popular demand for teachers' competency test (Salawudeen, 2012). 


\subsection{Purpose of the Study}

The purpose of the study was to investigate student-rating of teaching behaviour of Chemistry teachers in public secondary schools in Ekiti State. The study also investigated the degree of homogeneity between each component of teaching behaviour and the composite of teaching behaviour as well as determining whether gender bias would exist in students' rating of their teachers' teaching behaviour.

\subsection{Research Questions}

The following research questions were raised to guide the study:

1. How do the students rate teaching behaviour of their Chemistry teachers?

2. Is there any homogeneity between the rating ascribed to each category of teaching behaviour and the composite of teaching behaviour?

3. Is there any gender bias in the ratings ascribed to teaching behaviour of male and female Chemistry teachers by male and female students?

\subsection{Research Hypotheses}

The following hypotheses were tested at 0.05 level of significance.

$\mathrm{HO}_{1}$ : There is no significant homogeneity (correlation) between the rating ascribed to each c category of teaching behaviour and composite of teaching behaviour

$\mathrm{HO}_{2}$ : There is no significant gender bias in the rating ascribed to teaching behaviour of male and female Chemistry teachers by male and female students.

\section{Methodology}

\subsection{Research Design}

The research design was a combination of survey and $2 \times 2$ factorial design. The survey was to describe the direction of rating (excellent or poor) ascribed to teaching behaviour of Chemistry teachers by the students while factorial design was to compare the pattern of ratings ascribed to male and female teachers by male and female students.

\subsection{Sample and Sampling Techniques}

The sample for the study consisted of 750 SS II Chemistry students selected from 75 secondary schools across the 16 local government areas of Ekiti State, based on purposive and stratified random sampling techniques. The selection of SS II students was purposively done to arrest the mass failure recorded at that level during the 2011/2012 Joint Promotion Examination conducted by the Ekiti State Government where some schools are having no candidates in SS III in the current 2012/2013 session, while the stratum recognised males $=375$ and females $=375$.

\subsection{Research Instrument}

The instrument for collecting data was a 30-item Teaching Behaviour Questionnaire (TBQ) clustered into seven components or categories $\left(\mathrm{CAT}_{i}=1,2,3, \ldots\right) . \mathrm{CAT}_{l}=$ attendance and punctuality (two items), $\mathrm{CAT}_{2}=$ teachers' personality (six items), $\mathrm{CAT}_{3}=$ class management and organisation (three items), $\mathrm{CAT}_{4}=$ competence in teaching Chemistry concepts (nine items), $\mathrm{CAT}_{5}=$ disposition to laboratory work (two items), $\mathrm{CAT}_{6}=$ relationship with students (three items) and $\mathrm{CAT}_{7}=$ evaluation of students' works (five items). Each item was rated on a five-point scale namely Excellent $=5$, Very Good $=4$, Good $=3$, Fair $=2$ and Poor $=1$. The validity procedures (face, content and construct) were carried out using experts in Tests and Measurement in the Faculty of Education, Ekiti State University, Ado-Ekiti who vetted and made necessary corrections for the final draft. The reliability coefficient of the instrument was estimated at 0.713 using Cronbach $-\alpha$.

\subsection{Data Collection}

Data were collected using research assistants, mainly the Heads of Department of Science in all the schools sampled. Data were analysed using means, standard deviations, item-total correlations and t-test statistics at 0.05 level of significance.

\section{Results \& Discussion}

\subsection{Results}

Question 1: How do the students rate the teaching behaviour of their Chemistry teachers?

Data were analysed using means and standard deviations of ratings ascribed to each category. The assumption was that the mean values from 1.0 to 1.49 implies Poor; 1.50 to 2.49 (Fair), 2.50 to 3.49 (Good), 3.50 to 4.49 (Very Good) and 4.50 to 5.0 (Excellent). 
Table 1. Means and standard deviations of students' rating of teaching behaviour of teachers

\begin{tabular}{lll}
\hline Variables & Mean & SD \\
\hline $\mathrm{CAT}_{1}$ & 4.11 & 0.64 \\
\hline $\mathrm{CAT}_{2}$ & 3.27 & 0.81 \\
\hline $\mathrm{CAT}_{3}$ & 3.23 & 0.76 \\
\hline $\mathrm{CAT}_{4}$ & 3.28 & 0.72 \\
\hline $\mathrm{CAT}_{5}$ & 2.56 & 1.03 \\
\hline $\mathrm{CAT}_{6}$ & 3.21 & 0.71 \\
\hline $\mathrm{CAT}_{7}$ & 4.07 & 0.61
\end{tabular}

Maximum rating $=5, \quad$ Minimum rating $=1$

Table 1 shows the means and standard deviations of rating ascribed to $\mathrm{CAT}_{1}, \mathrm{CAT}_{2}, \mathrm{CAT}_{3}, \mathrm{CAT}_{4}, \mathrm{CAT}_{5}, \mathrm{CAT}_{6}$, and $\mathrm{CAT}_{7}$ as $4.11(0.64), 3.27(0.81), 3.23(0.76), 3.28(0.72), 2.56(1.03), 3.21(0.71)$ and $4.07(0.61)$ respectively. These results showed that teachers' punctuality and attendance in class as well as evaluation of students' work were rated as being very good while teachers' personality, class management and organisation, competence in teaching Chemistry concepts, disposition to practical work and relationship with students were rated as being good. This implies that the teaching behaviour of Chemistry teachers was good.

\subsection{Testing of Hypotheses}

$\boldsymbol{H O}_{1}$ : There is no significant homogeneity (correlation) between the rating of each component of teaching behaviour and composite of teaching behaviour (TB)

Data were analysed item-total correlations and the matrix is as presented in table 2 .

Table 2. Correlations between components and composite of TB means and standard deviations of students' rating of teaching behaviour of teachers

\begin{tabular}{l|l}
\hline Category of TB & Composite of TB $(\boldsymbol{r})$ \\
\hline $\mathrm{CAT}_{1}$ & $0.61^{*}$ \\
\hline $\mathrm{CAT}_{2}$ & $0.57^{*}$ \\
\hline $\mathrm{CAT}_{3}$ & $0.49^{*}$ \\
\hline $\mathrm{CAT}_{4}$ & $0.42^{*}$ \\
\hline $\mathrm{CAT}_{5}$ & $0.27^{*}$ \\
\hline $\mathrm{CAT}_{6}$ & $0.46^{*}$ \\
\hline $\mathrm{CAT}_{7}$ & $0.61^{*}$ \\
\hline \multirow{2}{*}{$p<0.05$ (Significant results) }
\end{tabular}

Table 2 shows that the r-calculated for $\mathrm{CAT}_{1}-\mathrm{CAT}_{7}$ and composite of teaching behaviour were $0.61,0.57,0.49,0.42$, $0.27,0.46$ and 0.61 respectively. All the results were positive and significant indicating that the ratings were homogenous.

$\mathrm{HO}_{2}$ : There is no significant gender bias in the rating of teaching behaviour of male and female teachers by male and female students

The mean total score per school was computed to represent the score of either male or female teacher and analysed using t-test as presented in table 3 .

Table 3. t-test comparison between ratings of male and female teachers by male and female students

\begin{tabular}{|c|c|c|c|c|c|c|c|}
\hline Variables & Teachers & $\mathrm{N}$ & Mean & SD & $\mathrm{df}$ & t-cal & $t$-value \\
\hline \multirow[b]{2}{*}{$\begin{array}{l}\text { Male } \\
\text { students }\end{array}$} & Male & 42 & 128.7 & 10.2 & & & \\
\hline & Female & 33 & 131.4 & 9.81 & 73 & 1.17 & 2.00 \\
\hline \multirow[b]{2}{*}{$\begin{array}{l}\text { Female } \\
\text { students }\end{array}$} & Male & 42 & 129.8 & 10.6 & & & \\
\hline & Female & 33 & 132.3 & 9.72 & 73 & 1.06 & 2.00 \\
\hline
\end{tabular}

Maximum score $=150$, Minimum score $=30$

$\mathrm{p}>0.05$ (Not significant results)

Table 3 shows that the mean scores and standard deviations (SD) of ratings ascribed to male and female teachers by male students were $128.7(10.2)$ and 131.4 (9.81) respectively. The t-calculated was 1.17 while its corresponding table value at 0.05 level of significance was 2.00. Since $t_{\text {cal }}<t_{\text {table }}$, it implies no significant difference. Hence no gender bias in rating. Similarly, the means and standard deviations (SD) of ratings of students to male and female teachers by female students were 129.8 (10.6) and 132.3 (9.72) respectively. The t-calculated was 1.06 while its corresponding table value 
at 0.05 level of significance was 2.00 . Since $t_{\text {cal }}<t_{\text {table }}$, it implies no significance difference. Hence, no gender bias in rating.

\section{Discussion}

The focus in this study centred on student rating of teaching behaviour of Chemistry teachers in public secondary schools in Ekiti State. The results in table 1 showed that students rated each category of teaching behaviour as being good or very good. For example, teachers' attendance and punctuality in class as well as evaluation of students' work were rated as being very good which concur with what Moore (2003) described as a mark of responsibility, commitment and seriousness with which they take their job. Interestingly, other categories of teaching behaviour such as teacher's personality, class management and organisation, competence in teaching Chemistry concepts, disposition to laboratory work and relationship with students were rated as being good. However, the rating ascribed to disposition to laboratory work was low as the rating ranged from poor to good. Since the students were in the best position to provide valid and reliable information about the activities in the laboratory, it could be inferred that not much activity took place in the laboratory which tends to confirm the finding of Okebukola (1987) that teachers' attitudes to Chemistry laboratory work contributed lowly to students' performance in Chemistry. Unarguably, Chemistry is an experimental science and teaching and learning of Chemistry without laboratory activity is an exercise in futility which may jeopardise the growth of Chemistry education in the state.

The results in table 2 showed significant relationship between each category of teaching behaviour and composite (overall) teaching behaviour. More importantly, all the correlation coefficients were positive. The usual rule of thumb for item-total correlation is that items should correlate with the total items by more than 0.20 to satisfy reliability (homogeneity) and scale assumption (Streiner \& Norman, 2003; Bowling, 2009). Since the correlation coefficients were higher than 0.20 , it implies that the rating ascribed to each category of teaching behaviour of Chemistry teachers was reliable. This tends to negate the impression that some teachers were incompetent in their teaching subject (Salawudeen, 2012). Deductively, Chemistry teachers in public secondary schools in Ekiti State may not be liable to poor performance of students in Chemistry but the students themselves.

The results in table 3 showed no significant gender bias in students' rating of teaching behaviour of male and female teachers in Chemistry as t-calculated in both cases were lower than the table-value of 2.0 at 0.05 level of significance. These results tally with the finding of Riger (1993) who reported no significant gender difference in evaluation based on gender of the teachers but noted that when differences in the mean scores were compared, female teachers received lower ratings than male teachers. However, in the present study, both male and female students rated the female teachers higher than the male teachers. Maybe the female teachers were more friendly and caring. Notwithstanding, since no significant difference was found, the slight increase in the mean scores of female teachers could be attributed to error of generosity and central tendency (Ary, Jacobs \& Razavieh, 2002).

\section{Conclusion}

It could be concluded in this study that the teaching behaviour of Chemistry teachers in public secondary schools in Ekiti State was good based on students' ratings. Moreover, the rating ascribed to each category of teaching behaviour of teacher was statistically reliable while gender bias in students' rating of male and female teachers was insignificant.

\subsection{Recommendations}

Based on the findings and conclusion, the following recommendations were made:

1. Chemistry teachers should justify the rating ascribed to their teaching behaviour by improving on their pedagogical skills to enhance better learning and performance of students in Chemistry.

2. Chemistry teachers should encourage their students to evaluate their teaching behaviour regularly while the feedback obtained from such evaluation be used to modify teaching and learning of Chemistry by the students.

3. Chemistry teachers should develop positive disposition to laboratory work in Chemistry so as to develop in the students appropriate process skills for the present and future advancement in chemical education.

4. Students should be courageous enough to provide valid and reliable information about their teachers, irrespective of gender so as to develop confidence and sound relationship for better learning and performance in Chemistry.

\section{References}

Adesoji, F. A., \& Olatunbosun, S. (2008). Student, teacher and school environment factors as determinants of achievement in senior secondary school Chemistry in Oyo State, Nigeria. The Journal of International Social Research. 1\&2: $13-34$.

Ary, D.; Jacobs, L. C. \& Razavieh, A. (2002). Introduction to research in education (6 $6^{\text {th }}$ ed.). Wadsworth Thomson Learning. 230-233.

Bagco, N. \& Simsek, S. (1999). The influence of different teaching methods in teaching Physics subjects on students' success. The Journal of Gazi Education Faculty. 19(3): 79-88.

Berk, R. A. (2005). A survey of 12 strategies to measure teaching effectiveness. International Journal of Teaching and Learning in Higher Education. 17(1): 48-62. 
Bowling, A. (2009). Research methods in health investigating health and health services ( $3^{\text {rd }}$ ed.). McGraw-Hill, Open University Press. 164.

Cooper, H. \& Hyland, R. (2000). Children's perceptions of learning with trainee teachers. London: Routledge.

Cross, S.; Dooris, M. \& Weinstein, S. (2004). Student rating of teaching effectiveness. Schreyer Institute for Teaching Excellence, Pennsylvania State. http://www. schreyerinstitutepsu.edu/pdf.

Doyle, T. (2004). Evaluating teacher effectiveness. Research Summary Centre for Teaching, Learning and Faculty Development. Ferris State University. Wordpress.com.

Erdle, S.; Murray, H. G. \& Rushton, J. P. (1985). Personality, classroom, behaviour and college teaching effectiveness: A path analysis. Journal of Educational Psychology. 17: 394 407.

Finlagson, M. (2009). The impact of teacher absenteeism on students' performance. The case of Cobb County School District. Practicum paper, Kennesaw State University. Available online at http://digitalcommons.kennesaw.edu. 14:1— 37.

Fox, R. (1983). Student evaluation of teacher as a measure of teacher behaviour and teacher impact on students. Journal of Educational Research. 77(1): 16-21.

Gaubatz, N. (2000). What's the use of student ratings of teaching effectiveness? http:// wwww.csti.syr.edu/csti/TL/stdrate.htm.

Kolawole, E. B. (2010). Principles of tests construction and administration. Lagos: Bolabay Academic Publishing Consultant. 18.

Linse, A. R. \& Xie, H. (2011). Student ratings of teaching effectiveness analysis of data from common courses from select semester (2009-2010). Schreyer Institute for Teaching Excellence. Pennsylvania State University. http://www.sttepsu.edu. Online report.

Maja, L. (2012). Self-evaluation of pre-school teacher competence checklists for self-evaluation. Journal of Educational and Social Research. 2(2): 11-20.

Maria-30 (2009). The importance of punctuality. www.course.notes.org. Retrieved 4th August, 2012.

Marlin, J. W. (1987). Student perception of end-of-course evaluation. Journal of Higher Education. 58: 704-716.

Marsh, H. W. (1987). Students' evaluations of university teaching: Research findings, methodological issues, and directions for future research. International Journal of Educational Research. 11: 253-388.

Marzano, R. J. (2003). What works in schools, translating research into actions. Alexandria, VA AOCD.

Moore, R. (2003). Attendance and performance. Journal of College Science Teaching. 32(6): 367-371.

Morgu, I.; Seyhan, H. G. \& Secken, N. (2009). Investigating the effects of project-oriented Chemistry experiments on some affective and cognitive field components. Journal of Turkish Science Education. 6(1): 108-114.

Murray, H. G. (2005). Student evaluation of teaching: Has it made a difference? A paper presented at the annual meeting of the Society for Teaching and Learning in Higher Education. Charlottetown, Prince Edward Island. June 115. www.stihe.ca.

Okebukola, P. A. (1987). Students' performance in practical Chemistry. A study of some related factors. Journal of Research in Science Teaching. 24(2): 119-126.

Olupohunda, B. (2012). 2012 WASSCE failure: Who is to blame? The Punch; Editorial Opinion. Thursday, August 23. 49.

Oluwatayo, J. A. \& Adebule, S. O. (2009). Programme and school evaluation. Ado-Ekiti: Sarka Printing Press.

Pollard, A. (2006). Reflective teaching $\left(2^{\text {nd }}\right.$ ed.). British Library Cataloguing-in-Publication Data. 119-123.

Prave, R. S. \& Baril, G. I. (1993). Instructors rating. Controlling for bias from initial student interest. Journal of Education for Business. 68: 362-366.

Rice, R. E.; Stewart, L. P. \& Huber, A. (2000). Extending the domain of instructional effectiveness, assessment in student evaluation of communication course. Communication in Education. 40: 253-266.

Riger, S. (1993). Gender bias in students evaluation. Journal of Educational Psychology. 91: 170—179.

Salawudeen, S. (2012). Teachers' competency test: Not ploy to sack. The Nation; Wednesday, May 23. 54.

Seldin, P. (1993). The use and abuse of student rating of professors. Chronicle of Higher Education. 39(40): 40.

Streiner, G. L. \& Norman, D. R. (2003). Health measurement scales. A guide to their development and use ( $3^{\text {rd }}$ ed.). Oxford: Oxford University Press.

Theall, M. \& Franklin, J. (1990). Student rating of instructions: Issues for improving practice. New Direction for Teaching and Learning. 43, San Francisco: Jessey-Bass.

Tope, O. (2012). Effects of teachers' competence on students' academic performance: A case study of Ikeja Local Government Area of Lagos State. www.facebook. com/omoleretope.

Trout, P. (2000). 'Student rating of teaching. The research revisited.' Idea paper; number 32. Kansas State University, Centre for Faculty Development.

Ugbe, A. U. \& Agim, J. J. (2009). Influence of teachers' competence on students' academic performance in SSS Chemistry. Global Journal Educational Research. 8(1\&2). 